Article

\title{
Islamic Education: An Islamic “Wisdom-Based Cultural Environment" in a Western Context
}

\author{
Fella LahmariD
}

Markfield Institute of Higher Education, Leicestershire LE67 9SY, UK; fella.lahmar@gmail.com

Received: 16 June 2020; Accepted: 4 August 2020; Published: 7 August 2020

check for updates

\begin{abstract}
As the number and types of Islamic schools in a Western context have increased, so too have the questions on their purpose and impact in pluralistic Western societies. Amid this increasingly complex environment, questions are raised, both internally and externally, to determine the nature of Islamic educational goals, schools' knowledge and pedagogical practices. Analysis in this paper draws on multiple sources of data: classical and contemporary literature on education in Islam; the Department for Education (DfE) school census and the Office for Standards in Education; Children's Services and Skills (Ofsted); and empirical case-study data extracted from the author's PhD thesis on diversity in Islamic schools in Britain conducted during 2008-2012 and subsequently revised during 2018-2019 by following up emergent themes. This paper argues for a need to develop an "Islamic wisdom-based culture" promoting action ('amal) which nurtures the holistic growth of learners in ethical areas (akhlāq), aesthetics (dhawq/jamāl) and develops a sense of freedom (huriyyah). By doing so, the paper draws primarily on Bennabi's analysis of the role of culture (thaqäfah) in the civilisation cycle, Ibn-Khaldūn's analysis of freedom and dignity in educational practice embedded in his discussion of the meanings of humanity) Al-insāniyyah) and Gadamer's analysis of "practical wisdom". Firstly, it contextualises Islamic schooling in Britain into a neoliberal pluralistic context. The wisdom inherent in Islamic education is explored through critical dialogue during the process of learning and action. The discussion then considers three key elements of "wisdom-based cultural environment" for Islamic education.
\end{abstract}

Keywords: Muslim schools; Islamic education; Islamic schools; philosophy of education; culture; Islamic environment; wisdom; Bennabi; Ibn-Khaldun; Al-Ghazali

\section{Introduction}

It is generally accepted that education forms an important role in achieving a better future for both the individual and society. What constitutes education and its aims, however, remains

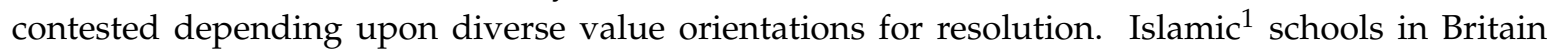
intersect with different Muslim backgrounds and experiences, providing a contested space for dialogue between national concepts of Britishness and Islam (as a lived religion) (Cheruvallil-Contractor and Scott-Baumann 2015; Lahmar 2019). When preparing future citizens, Islamic school educators are expected to serve society by critically understanding the nature and needs of their diverse Islamic community, those of the wider society to which these learners belong and to respond to a range of demands and pressures. Moreover, in light of extremist threats, Muslim educational leaders are forced to publicly define and interpret their varying religious understandings and cultural practices in relation to the dominant British socio-political context (Holmwood and O'Toole 2018; Lahmar 2012, 2019).

1 Islamic schools in this paper refer to schools that operate explicitly as schools driven by an Islamic ethos. 
Such a situation demands critical reflexive dialogical understanding amongst diverse Muslim communities and between Muslims and their pluralistic Western contexts (Abdalla et al. 2018; Lahmar 2011b). For Nasr (2016), the role of Islamic education in a globalised context is to resist homogenisation, build bridges with diverse cultural contexts and preserve its unique framework while creatively and authentically revive from within, thus benefiting from others by incorporating harmonious elements compliant with its principles. Acquiring such goals demands intellectual criticality to absorb, appraise and reject forms of modern knowledge. This process, Nasr (2016, p. 25) argues, requires "an Islamic philosophy and praxis of education" pursuing a creative contemporary revival within an authentic Islamic educational system. Muslim educators are challenged to think creatively about Islamic education (Memon et al. 2020; Davids and Waghid 2019; Hashim et al. 2014). This paper contributes to this ongoing debate by considering the question: What aspects are essential to the cultural environment of an Islamic educational institution in order to nurture creative and wise social actors?

Analysis here draws on multiple sources of data: the Department for Education (DfE) school census and the Office for Standards in Education; Children's Services and Skills (Ofsted) school reports; and the empirical qualitative case-study data extracted from the author's PhD thesis on diversity in Muslim schools in Britain conducted during 2008-2012 (Lahmar 2012). In this paper, the analysis specifically refers to headteachers' perspectives and parental semi-structured interviews and qualitative questionnaire data in the six case-study schools ${ }^{2}$. The paper also draws on semi-structured headteachers' interview data from a follow-up assessment of two schools (London Independent Primary School (London-PS) and Vision Independent Secondary School (Vision-SS) during 2018-2019. The two latter case-study schools' publicly available letters, value and mission statements, curriculum provision and Ofsted reports were also revisited. Data were coded and analysed using NVivo software. Both phases of the study followed the ethical approval procedures required by the research institutions prior to data collection. Theoretical discussion draws on both classical and contemporary literature, including three types of tafsir of a Qur'anic verse (02: 269) on hikmah (wisdom), along with Ibn-Khaldūn's sociological analysis on discipline in education and Bennabi's framework of cultural components.

The first section briefly contextualises Islamic schools in Britain within a neoliberal context. It also examines the concept of "wisdom" as an Islamic educational goal essential for critical reflexive dialogue between these schools and their contexts. The second part introduces the idea of an "Islamic environment" as an emergent theme drawn from parental expectations of Islamic schooling. The discussion then questions the concept of an educational "Islamic environment" and its attendant culturally effective elements. Drawing on Bennabi's analysis of cultural renaissance components, focus is placed specifically on two primary elements of ethics and aesthetics. Finally, Ibn-Khaldūn's proposal adds a third component, "freedom and dignity", for nurturing social actors in an educational culture fortified by Islamic values. Gadamer (1989) concept of "practical wisdom" underpins this paper's analysis of achieving "the right measure" in theory and practice within Islamic education.

\section{Islamic Education in a Context of Choice and Pluralism}

\subsection{The Neoliberal Western Context of Islamic Education}

In Britain, faith and education have been closely connected. The 1944 Education Act allowed religious schools to be drawn under the state system as partners (Gates 2005). Accordingly, within a multicultural policy context, some Muslim educationalists sought to align with state sectors to serve the religious needs of Muslim children from within the system (Lahmar 2011a, Parker-Jenkins et al. 2005). Segregation, the marginalisation of girls and a lack of professionalism and resources were

2 Six schools from four different locations in England: the Andalusia-state funded secondary school (Andalusia-SS); Iqra-independent secondary school (Iqra-SS); London-independent primary school (London-PS); Olive-independent primary school (Olive-PS); Message-state funded primary school (Message-PS); and Vision-independent secondary school (Vision-SS) were selected for inclusion in the study. All names are pseudonyms. 
key concerns levied against Islamic schools during the 1990s (Haw 1994). However, Islamic schools in Britain continue to grow in number, secure state funding for different types of schools, develop professional practice and gradually build resources (AMS-UK 2019b). For example, Muslim schools managed to secure the top three positions in the overall performance of all pupils at the end of key stage 4 in 2019 across all schools and colleges in England (GOV.UK 2019).

Though, based on an overview by the Association of Muslim Schools UK (AMS-UK 2019a) reviewing Muslim schools in the UK (2013), 95\% of Muslim children attended mainstream state schools. The remaining 5\% of Muslim children were attending Muslim schools, including 23\% who were attending state-funded Muslim schools and the remaining 77\% were attending independent Muslim schools (AMS-UK 2019b). In 2014, there were 156 registered Muslim schools in the UK, the majority of which (120 schools) were affiliated to the AMS-UK (2019a). However, the number of both state-funded and independent Muslim schools is dynamic. Table 1 shows the limited but steady growth of Muslim state-funded schooling in England and the increase in their population of full-time pupils across five consecutive years.

Table 1. State-funded Muslim schools in England between 2015/2016 and 2019/2020.

\begin{tabular}{|c|c|c|c|c|c|c|}
\hline & & $2015 / 2016$ & $2016 / 2017$ & $2017 / 2018$ & $2018 / 2019$ & $2019 / 2020$ \\
\hline \multirow{4}{*}{$\begin{array}{l}\text { State-funded } \\
\text { primary }\end{array}$} & Full-time pupils & 3632 & 4455 & 5002 & 5538 & 6315 \\
\hline & $\begin{array}{l}\mathrm{N} \text { (per cent of the } \\
\text { number of full-time } \\
\text { pupils in the } \\
\text { state-funded primary } \\
\text { schools in England) }\end{array}$ & $(0.08 \%)$ & $(0.10 \%)$ & $(0.11 \%)$ & $(0.12 \%)$ & $(0.13 \%)$ \\
\hline & Number of schools & 10 & 13 & 13 & 14 & 15 \\
\hline & $\begin{array}{l}\mathrm{N} \text { (per cent of the } \\
\text { number of state-funded } \\
\text { primary schools in } \\
\text { England) }\end{array}$ & $(0.06 \%)$ & $(0.08 \%)$ & $(0.08 \%)$ & $(0.08 \%)$ & $(0.08 \%)$ \\
\hline \multirow{4}{*}{$\begin{array}{l}\text { State-funded } \\
\text { secondary }\end{array}$} & \multirow{2}{*}{ Full-time pupils } & 5577 & 6332 & 7422 & 8491 & 8939 \\
\hline & & $(0.17 \%)$ & $(0.20 \%)$ & $(0.22 \%)$ & $(0.25 \%)$ & $(0.26 \%)$ \\
\hline & \multirow{2}{*}{ Number of schools } & 14 & 14 & 16 & 17 & 18 \\
\hline & & $(0.41 \%)$ & (0.41\%) & $(0.46 \%)$ & $(0.49 \%)$ & $(0.52 \%)$ \\
\hline
\end{tabular}

Source: Schools, pupils and their characteristics (GOV.UK 2020).

The "Trojan Horse Affair", as it came to be known, is a plot alleged to have occurred in several Birmingham schools during 2014, which placed some Muslim educational activists at the heart of debates surrounding fear of Islamising mainstream British schools and nurturing extreme versions of Islamic religiosity (Holmwood and O'Toole 2018). The charges of radicalisation and extremism were later revealed to lack substance. However, on 27 November 2014, the DfE (2014) published guidance on promoting Fundamental British Values (FBV) in schools as a requirement for pupils' social, moral, spiritual and cultural (SMSC) development. The FBV include: "democracy, the rule of law, individual liberty, and mutual respect and tolerance of those with different faiths and beliefs" (DfE 2014). In such a context, Islamic schools, both independent and state-funded, fall under intense scrutiny and suspicion regarding how FBV are promoted.

The trojan horse at the time had a massive impact on all Muslim schools, generally, because there was a massive attack on Muslim schools, very very negative, and I have to say it is a credit to the AMS, they have worked extremely hard with the DfE in particular, side by side to make sure that Muslim schools revise their policies, their practices and there is no misunderstanding. (Headteacher, Vision-SS, November 2018) 
Hence, these schools stand within the multiple tensions between independence and state funding status, Islamic ethos and academic achievement, Britishness and Muslimness, religion and culture, integration and segregation, extremism and Muslim unity and diversity (Lahmar 2019, 2012). Specifically, Islamic schools with an Islamic ethos are developing within a market characterised by a competitive environment where funding, choice and policies are pushing school leaders to make pragmatic choices. The following headteacher's account illustrates part of that growth and struggle:

Since 2012, I think more and more schools have opened since then. Two things happened; the independent school standards the DfE raised the bar, they introduced some new standards around SMSC, spiritual, moral, social and cultural, and they also introduced the leadership management standard. Then, Ofsted on the back of that went in with renewed vigour, let's say, and periodically, they raised the bar again, raised the bar again. The [sigh] framework for assessment was rewritten, it became a common framework for assessment for schools that were in the independent sector and the maintained sector. Some schools have had to close as a result of all of this; because they didn't have the capacity or the support of the leadership to be able to turn themselves around as quickly necessarily as needed. The vast majority, I think, that had tough inspections have improved. (Headteacher, London-PS, December 2018)

Ofsted judges schools across four main areas: quality of education, behaviour and attitudes, personal development and leadership and management. Accordingly, the inspection judgements grade schools on a four-point scale: outstanding, good, requires improvement and inadequate (Ofsted 2019b). For example, as of 31 August 2019, Ofsted (2019a) inspected 135 non-association independent Muslim schools with 19,000 pupils on their rolls. The inspection effectiveness judgement results report $8 \%$ as "outstanding", 53\% as "good", 20\% as "requiring improvement" and 19\% as "inadequate". The Ofsted inspection judgment on schools' performance is an important factor regarding how these schools are publicly presented; at times, this may mean resorting to court adjudication for the school to remain functioning (BBC 2017).

However, independent schools and faith groups can establish "free schools" type, which are funded by the government, are not run by the local education authority and are "all-ability" non-academic selective schools which do not have to follow the national curriculum (GOV.UK n.d.). The Vision-SS headteacher believes that an increase in the number of "free schools" has a potentially negative impact on student recruitment in the independent sector of Islamic schooling that offers a more explicit focus on religiosity:

There is a massive increase on free schools, and free faith schools with Muslim character and then parents will say: 'look, although I wish my child to come here because they are exposed fully to the faith, I'd still I don't have to pay!' So, that obviously have an impact on our school, yeah, and I think it will continue to have an impact; because there is a growth in this area. (Headteacher, Vision-SS, November 2018)

The development of the Star Academies, from a Muslim school into a mixed Multi-Academy Trust running a diverse network of primary and secondary schools, is an example of the continued change in Islamic schooling provision (Star Academies 2020), form and vision in the British context.

In the free school sector, there has been a vast proliferation from one multi-academy trust which is Star ${ }^{3}$ Institute now it's called, previously called the Tauheedul Education Trust. They are schools that have really thought about the demography and the problems and the context and what needs to be addressed, and they've catered their curriculum towards meeting those things. (Headteacher, London-PS, December 2018) 
Research into theories and practices in Islamic/Muslim schools in Britain and Europe is a developing area (Abdalla et al. 2018; Cheruvallil-Contractor and Scott-Baumann 2015). Questions are raised about the goals of Islamic education in a Western context; many researchers called for a critical reflexive dialogue between Islamic heritage and Western educational traditions (Lahmar 2011b, 2012; Niyozov and Memon 2011; Sahin 2013).

\subsection{Islamic Education: Critical Reflexive Dialogue}

\subsubsection{Critical Reflexive Dialogue}

The Arabic terms of $t a^{\prime} d i b$, tarbiyah and t $a^{\prime}$ lim $m$ express three different dimensions in the educational process offering various views of the most encompassing concepts within Islamic education (Al-Attas 1991; Halstead 2004; Sahin 2013). However, additional concepts reflect other aspects of education in Islamic heritage, such as talqin (inculcation), tablīigh (proclamation), tazkiyah (purification/growth), tahdīi (refinement/edification) and iṣlăh (reform/improvement). Thus, claims of an all-encompassing concept of education in Islam remain open to dispute. Classical debates on the goals of education were all, at different degrees, priorities and approaches, based on the consideration of revelation as a key source of knowledge, the Prophet as an embodiment of the message and the appreciation of the role of reason and spiritual experience in attaining knowledge of God and His creation. Classical literature on education from Islamic thought include that of Ibn-Sahnūn (819-870 CE), Al-Farābī (847-950), Al-Qābisī (935-1012), Ibn-Sīnā (980-1037), Ibn-Miskawayh (1030-1130), Al-Ghazālī (1058-1111), Ibn-Rushd (1126-1198), Rumī (Moulavi) (1207-1273), Ibn-Taymiyyah (1263-1328) and Ibn-Khaldūn (1392-1406), amongst many others.

A recent resurgence of debates for and against the Islamisation of knowledge project offer the prospect of generating intra-Muslim discussions and support for developing new visions for Islamic education that are open to dialogue and critical engagement through different contexts. While not the place to assess different proposals within Islamisation theory, two main approaches emerged, namely epistemological and ethical (Niyozov and Memon 2011; Rahman 1988; Al-Faruqi 1988; Al-Attas 1991). In this regard, Niyozov and Memon (2011) rightly demand the re-examination of the epistemological and methodological assumptions and approaches of the Islamisation project with its diverse interpretations in light of an inclusive critical approach of the self and the other. By doing so, Islamic education is required to "produce new knowledge and re-define its content, goals, and pedagogy on this basis" (Niyozov and Memon 2011, p. 25).

Similarly, I argued that "[s]eeking wisdom from whatever source is an Islamic Prophetic teaching which [ ... ] demands critical reflexive dialogue with the other" (Lahmar 2011b, p. 14). The critical reflexive dialogical understanding is required, not only between Muslims and their Western contexts, but also amongst diverse groups of Muslims. The implications of such internal and external dialogues would contribute to the development of common Islamic educational aims and curriculum resources in a contemporary context (Lahmar 2011a). However, the process of moving backwards or forwards between educators' Islamic heritage, diverse experiences, Western cultural contexts and global changes necessitates "new types of flexible personal controls, dispositions and means of orientation" (Featherstone 1990, p. 8). Navigating this complexity and recognising what is "relevant" and "appropriate" to the situation demands more than technical knowledge about Islam; it requires developing a critical reflexive questioning of one's action, and that entails ethical and moral considerations towards the self and others. Technical "recipes" seeking ready-made formulas for Islamic educational practice require abandonment; self-reflexivity and contextual understanding become essential parts to arriving at that "right measure" (Lahmar 2011a, 2011b).

\subsubsection{Islamic Education for Wisdom}

Classical debate disputes the aim of attaining wisdom (hikmah) as an educational goal in Islam. This goal is supported by various Qur'anic texts, including Surah Luqmān where Luqmān is described 
as being a wise person of knowledge and an educator. Wisdom as a goal of education in Islam is also supported by the Qur'anic verse (02: 269): “Whoever is given wisdom [hikmah] has truly been given much good, but only those with insight [ulu Al-albāb] bear this in mind" (Abdel Haleem 2005, p. 31). Interpretations of this verse reflect the diversity within Muslim thought regarding the primary aims of education based on differing understandings of the Qur'an. It also questions the existence of a dichotomy between "Islamic" and a supposed "other".

For example, from a rationalist approach, the views of Al-Zamakhshari (1075-1144) (offering a rational Mu'tazilah approach) and Fakhr ad-Dīn ar-Rāzī's (1149-1209) (supporting rational theology and philosophy) differ on whether wisdom is attained through human faculties or bestowed as a divine gift based on the interpretation of $\bar{\imath} t \bar{a}$ ' (granting/bestowing). However, they both agree when considering "theoretical knowledge" ('ilm) and practical "right conduct" (sawab) as two key aspects of wisdom. For both, the practical commitment to theoretical knowledge is regarded as a requirement for any person to be considered "wise".

Fakhr Al-Dīn Al-Rāzī (Ar-Rāzī 1981) considers the judgment (hukm) of "wisdom" combined with "reason" as an essential element in the process of reaching unbiased accurate truth. In contrast to reason, Fakhr Al-Dīn Al-Rāzī (Ar-Rāzī 1981) regards the judgment (hukm) of a person's desire (shahwah) and soul (nafs) to be based on imagination and delusion, led by the urge of "achieving the present pleasure". For wisdom perceived as "the right conduct (ṣawab)", Fakhr Al-Dīn Al-Rāzī (Ar-Rāzī 1981) considers it as part of the human-being's journey in pursuing perfection (kamāl). The verse of wisdom ends by restricting remembrance (tadhakkur) to "those with insight" (albāb). In this sense, Fakhr Al-Dīn Al-Rāzī (Ar-Rāzi 1981) argues that critical reflection is a way of deepening faith in the heart by examining the already attained knowledge beyond an apparent layer of understanding to deeper layers of reflection on the essence. Fakhr Al-Dīn Al-Rāzī (Ar-Rāzī 1981) endorses the Mu'tazilah's opinion via their definition of wisdom (hikmah) as "the power of understanding and the development of evidence" regarding mindfulness (tadabbur), and reflection (tafakkur), of the necessary skills enabling the wise person to know the boundaries and realise the pros and cons of action before making an appropriate decision. For Al-Zamakhshari (2009, p. 151), "those with insight" are "the wise knowledgeable doers". Thus, wisdom (hikmah) necessitates theoretical knowledge and a continuous in-depth critical reflection process on practice by using the faculty power of $(l u b b)$ to reach the appropriate judgment.

In defining hikmah, Ibn-Qayyim (1292-1350) (Ibn-Qayyim 2008) selected the views of Mujāhid ${ }^{4}$ (d. 722) and Mālik ${ }^{5}$ (711-795) as: "knowledge of the truth (Al-haq) and acting upon it" and "righteousness in saying and doing", which Ibn-Qayyim restricted to understanding the Qur'an, rulings and other teachings of Islam and truths of creed. He (Ibn-Qayyim 2008) regards the tadhakkur and tafakkur as within the faculty of the heart (qalb). Ibn-Qayyim distinguishes between the level of tafakkur as the initial stage of understanding through reflection and tadhakkur as the upper stage of retrieval of what has been already attained. He further adds the concept of tabașsur (acuity/discernment) as a way to remind the heart of the evidence. Education for wisdom in this approach focuses on the heart and its relation to the Qur'an.

However, Ibn-'Āshūr (1879-1973) (Ibn-'Āshūr 1984, p. 61), a Tunisian prominent scholar and Islamic revivalist, in his Qur'anic exegesis, Al-Tahrir wa Al-Tanwir (Liberation and Enlightenment), which is influenced by a maqāsidī (higher objectives of Shari'ah) approach in responding to modernity, defines wisdom as "mastering knowledge and conducting action according to that knowledge". He (Ibn-'Āshūr 1984, p. 61) refers to the meaning of wisdom as "judgment and prevention" because attaining wisdom "prevents from falling into error and misguidance". Given the condition of "mastering" knowledge, the definition that Ibn-'Āshūr (1984, p. 61) presents agrees with Fakhr Al-Dīn

4 A student of the Prophet's companion Ibn- 'Abbās; he is a key figure in the Qur'anic tafsīir school that had developed in Makkah.

5 Mālik-bin-Anas (711-795), the founder of the Mālikī school of jurisprudence. 
Al-Rāzī's view that wisdom is related to knowing "the objective reality of things as they are with what the [human] capability enables, i.e., so that similar facts do not get confused with each other ... ". Similarly, Al-Attas (1991), from a different analytical dimension, considers that a lack of knowledge and wisdom results in confusion. Unlike Ibn-Qayyim (2008), restricting sources of wisdom within classical Islamic fields of knowledge related to understanding the Qur'an, Ibn- 'Āshūr considered two basic sources, the divine, derived through revelation, and the human, attained through mental diligence and cross-fertilisation and development of ideas between different nations. He (Ibn-'Āshūr 1984) regards the work of Greek philosophers to represent a unique contribution in this process by refining and dividing it into "practical wisdom" and "theoretical wisdom". In his detailed discussion of Greek philosophers' contributions, Ibn-'Āshūr (1984, p. 73) examines "practical wisdom", including the science of ethics, which he claims is defined as abiding by "the character attributes of the Divine High according to human ability, which would [i.e. the divine] be the source of human perfection". This proposed Greek philosophers' definition, cited in Ibn-'Āshūr (1984) tafsīr, is identical to Fakhr Al-Dīn Al-Rāzī's (Ar-Rāzì 1981) in his tafsìr of the same verse offering a definition of wisdom as practice.

This sample of $t a f s i \bar{r}$ threads illustrate the complexity of the accumulated thought on education in Islam, even within the literature on Qur'anic commentary. Hence, the two worlds, East and West, are not mutually exclusive and modern European culture was not immune from Muslim intellectual heritage, influence and inspiration and vice versa (Iqbal 1999). Discussion on wisdom highlights the important relationship between knowledge and action in Muslim thought. In this regard, Bennabi (2006) argument is adopted in this paper, by stating that:

What is lacking in a Muslim is not the logic of the idea, but the logic of action and movement.

[The Muslim] does not think to act, but rather to say abstract words. (Bennabi 2006, p. 103)

Accordingly, the task of Islamic education is to re-instil this "logic of action and movement" into Muslim belief (Bennabi 2006). Certainly, advanced critical, analytical and debating skills to the level of Al-Burhān, as Ibn-Rushd (1997) contends, are necessary for scholarship. However, they do not form the driving component for moral ethical action; these skills remain at the realm of "the logic of the idea" as Bennabi (2006) skilfully analysed. The moral ethical action, as previously argued, constitutes a component of practical wisdom to attain "the right measure".

Certainly, from an Islamic perspective, moral ethical action is also connected to the notion of taqwá (God consciousness), which forms an important element in Al-Ghazālī's (1058-1111) ethical theory of human conduct. In the learning process, Al-Ghazāli considers both theory and practice, stating that "knowledge without work is insanity, and work without knowledge is vanity" (Al-Ghazali 2000a, p. 13). For him (Al-Ghazali 2000a, p. 21), tasting the light of knowledge does not come through "the ecstatic utterances and vehement cries of the Sufis", while neither comes through formal knowledge and rational reasoning of philosophers. However, in his book "The Incoherence of Philosophers", Al-Ghazali (2000b) accepts rational reasoning but uses it to reject metaphysics as a genuine route to true knowledge. For him (Al-Ghazali 1964), educational practice needs to encompass the internal spheres of the self, the soul, spirit and heart, which are part of Al-'aql (intellect/reason). This is because a person's selfish lower self of desires and lusts (shahwah) and soul (nafs) do not get disciplined through mere rational reasoning but through the struggle of "tazkiyah" by self-disciplinary exercises (mujāhadah) as an inner spiritual experience process of "tasting" (dhawq) (Al-Ghazali 2000a). It is this process of "tazkiyah" that takes the learner from the formal knowledge of rational reasoning to tasting the light of knowledge. Accordingly, Al-Ghazālī regarded the inner experience, or what he conceptualised as "tasting" (dhawq), of paramount importance to inner purification and, therefore, to the outer action. It is this moral inner ethical drive that Bennabi considers as a primary component to a cultural environment that promotes the logic of action; a view that this paper adopts to propose a "wisdom-based cultural environment" for Islamic education. 


\section{3. “Wisdom-Based Cultural Environment” for Islamic Education}

\subsection{The School Environment and Islamic Schooling in Britain}

During the initial 2012 study phase (Lahmar 2012), concepts of an "Islamic environment" and "practicing Islam" became conceptually significant, emerging from the data analysis, as referred to by the majority of parents via open-ended questionnaire responses and semi-structured interviews. Two main themes emerged across the schools in relation to an Islamic environment: first, helping children to establish confidence in their Islamic way of life; and, second, encouraging children to contribute to society (Lahmar 2012). However, parents presented different priorities regarding what constitutes "Islamic" within a school environment. The Islamic environment was not just centred on teaching Islamic subjects, but focused on codes of conduct in school, role modelling, dress, greetings and celebrations. Within such an environment, parents expected higher behavioural standards than those found in mainstream schools. Fostering a sense of belonging represents a key theme across parents and headteachers' responses in the 2012 phase of the study:

The [Olive-PS] environment is good; it has gone beyond my expectations of what I wanted. It gives me a lot of pleasure to hear Zeinab come home and pray salah, she's prayed there [... ]. It was such a nice atmosphere in the school, everybody excited and stuff, [ ... ]. I think it teaches them lots of things but it still teaches them to be happy in their own religion, and that is nice, they have got a sense of belonging. For however long it lasts it will not last forever, they will have to move on, [ ... ]. (Mother-2, interview, Olive-PS, 2012, emphasis added)

For a number of parents, pupils need to feel comfortable and "normal" when they are practising Islamic rituals, building love and confidence of their Islamic history and heritage and this demands a positive experience within Islamic schooling. Thus, a number of parents perceived the schools as supporting their parental role in helping children to balance various values, such as academic attainment and fitting in as Muslims within a British context:

For me it's like a weight lifted off my shoulder [ ... ]. I knew she is in a safe environment with people that understand, respect her religion, where she could feel proud of her religion and express herself, instead of feeling that she has to hide it away as something different. But then, you want your children to grow as good citizens and contribute to society and not get into any trouble. (Mother-2, interview, 2012, Vision-SS)

The educational Islamic environment, as described by the majority of parents and school leaders, pays particular attention to learners' religious needs in terms of ritual observance, dress code and community cohesion to improve Islamic practice and strengthen a sense of belonging (Lahmar 2012). Both themes of nurturing a sense of confidence in Muslim identity, and positively contributing to society are reemphasised by the two headteachers interviewed in the 2018-2019 phase. However, the discourse of social cohesion has been shifted to an emphasis on FBV as an embedded part of the school environment to prepare pupils as citizens for active roles in society. As part of serving parents' expectations, many independent Islamic schools emphasise their religious character as the Vision-SS headteacher (November 2018) stresses that: "there is a massive more emphasis on the religion of the school here [than in free schools]". However, some schools present different models of environments underpinned by Islamic ethos, including that of the Star Academies' example:

They [Star Institute] have a model which is different from our school. So, whereas in schools like mine and many others, actually most Muslim schools, we explicitly teach Qur'an, we explicitly teach Arabic, we explicitly teach Islamic Studies [... ] etcetera, whereas Tauheedul is different. They teach the spirit of Islam through social action, through behaviour, through appreciation, and they cater for Muslims within that environment [ ... ]; the embracing of Muslim identity and cultures. (Headteacher, London-PS, December 2018) 
To fathom the importance of cultural aspects within such an environment, the following analysis draws on Bennabi (2006) framework of "culture" to examine its role in educating Muslim learners towards developing an authentic sense of self and active creative agency.

\subsection{Islamic "Wisdom-Based Cultural Environment"}

Children in Muslim schools derive from diverse Muslim sub-communities, often cited within deprived educational and economic backgrounds, whereby a majority hail from immigrant family backgrounds albeit at different stages of arrival and settlement (Ofsted 2013; Lahmar 2012). Islamic school communities provide an internally diverse cultural sample, offering the potential to act as catalysts of change within distinct Muslim communities. Following Bennabi (2006) line of analysis, cultural transformation becomes a necessity within Islamic schooling as a civilising project, rather than as an Islamising decorative process. The change goes beyond the accumulation of prestigious objects, including premises and examination ranking, or decorative apparent superficial religiosity. It can be asserted that Islamic education should rather develop a new synthesis of human personality and its essential qualities to assume responsibilities within their given contexts. In this regard, Bennabi (2006) considers the decline within the Muslim ummah as embedded within its cultural norms, fostering individuals prone to internalising a sense of inferiority towards the dominant European colonisers. Furthermore, Bennabi (2006) suggests that with the decline of civilisation people lose their sense of agency, creativity and efficacy. Accordingly, they become imitators either stagnating within an idealised past or rejecting their heritage to adopt the look, behaviour and superficial consumerist borrowing from whom they see as superior. This argument partly relates to Ibn-Khaldūn (2005) theory that the dominated always imitate those who dominate them because they believe in their perfection.

Within this complexity, Bennabi (2006) links the problem of human beings directly to the problem of civilisation, whereby, culture becomes a context of a pivotal educational value. In his view, culture is a crucial social and educational agent of change in the process of reconstruction of the self to regain self-determination, efficacy, creativity and social agency. Although there is no universally accepted definition of culture, according to Kroeber and Kluckhohn (1952) definition, culture has "patterns" and "systems", the behaviour in which is "acquired" and "transmitted":

Culture consists of patterns, explicit and implicit, of and for behavior acquired and transmitted by symbols, constituting the distinctive achievement of human groups, including their embodiments in artifacts; the essential core of culture consists of traditional (i.e., historically derived and selected) ideas and especially their attached values; culture systems may, on the one hand, be considered as products of action, on the other as conditioning elements of further action. (Kroeber and Kluckhohn 1952, p. 181)

In applying such a definition of culture to analyse any particular Islamic school environment, two essential levels of depth can be regarded for observation: explicit and implicit patterns. The manifestations of such patterns include: ideas and values, artifacts that express some aspects of culture and control systems that produce actions and behavioural norms. In concert with these aspects, Bennabi (2006) differentiates between culture and knowledge, considering culture as a theory of behaviour. Accordingly, Bennabi (2006, p. 89) conceives culture as "the environment in which the individual forms his character and personality".

It is as Bennabi (2006) elaborates, culture is more general than knowledge and more closely related to issues influencing personality than to the collection of information. He (Bennabi 2006) defines culture as a process of being and becoming. In pedagogical terms, Bennabi (2006) cultural envisioning presents ethics, aesthetics, practical logic and technical skills as four elements of any civilisational change. Bennabi (2006) regards culture as the plasma within which human social relations are embedded and nurtured by the two primary components that determine its direction, namely ethics and aesthetics. However, nurturing a moral drive without risking a repulsive extreme reaction or indoctrination, or what Ibn-Khaldūn (2005) terms domestication remains a pertinent question. For Bennabi (2006), this 
requires nurturing the "aesthetic element", in its broad sense, as a second primary crucial component of culture towards productive action. For Ibn-Khaldūn (2005), and the Tunisian philosopher Al-Marzouqi (2015), the process requires nurturing a "sense of freedom" and dignity. Thus, this paper argues for the need to embed the three components within the Islamic educational environment: the ethical and moral reflexivity, the "aesthetics of $i$ is $\bar{a} n$ (excellence)" in its broader scope and the "sense of freedom and dignity".

\subsubsection{The Ethics and Morals Component}

Muslims amid this fast-changing global context, and within Western non-Muslim arenas, are required to be creative in navigating a path through heritage, present context, and envisioning their future status. Islamic educational institutions, including schools, are at the centre of such process. Their roles should not be restricted to cultural transmission, possibly resulting in stagnation within an idealised past, or adopting a passive consumeristic approach to the "dominant" present contexts, but rather to produce ideas and develop learners who are critical, creative and efficacious social agents. In doing so, the diversity within these schools need to be recognised and celebrated rather than denounced or suppressed under the guise of "one ummah". It is as Nasr (2016) states:

[W] hen we think about Islamic education, we must think of 'diversity within unity'. It is to discern the unifying elements in Islamic educational practice without ignoring the local differences. (Nasr 2016, p. 18; quotes in original)

Differences within the school environment need to be integrated into a coherent synthesis to be productive. Bennabi (2006) rightly insists that such integration is a condition for the development of efficacious actors able not only to acquire and transmit culture, but also to become producers of a rising creative culture. In this regard, he considers ethics and morals as an essential integrating cultural force stating that:

The role of the moral ideal is precisely to construct the realm of persons without which neither the realm of ideas nor that of objects will have any raison d'être. (Bennabi 2006, p. 95)

As for Muslims, ethics stem from divine revelation and religious spiritual connectedness. Missing such a cementing element would lead to the fragmentation of communities into isolated individuals who have no clear direction, and are unable to transmit their heritage, let alone produce any authentic renewed efficacious self (Bennabi 2006). For Bennabi (2006), the ethical component not only contains the force to unify and integrate different segments of society, but also determines the societal cultural orientation and transforms human action into a conscious deliberative and purposive praxis. His (Bennabi 2006) proposal of ethical and moral values as the essential core for action partly resonates with Al-Ghazālī's emphasis on "tazkiyah" to achieve taqwá (God consciousness) and self-discipline of the soul as necessary processes in attaining righteous action in harmony with spiritual goals. Unlike Fakhr Al-Dīn Al-Rāzī (Ar-Rāzī 1981), for both Al-Ghazālī and Bennabi (2006), directing the powers of desire (shahwah) and the soul (nafs) requires spiritual moral deliberation more than rational reasoning per se.

Prophetic teachings through the Qur'an and practice changed some essential elements underpinning cultural values in Madinan society; a change which gradually led to the erosion of the tribal 'așabiyyah ${ }^{6}$ in its pre-Islamic form. It was a challenging change that proved transformative to the companions' value system and self-confidence regarding their potential towards building a civilisation based on newly adopted Islamic beliefs and worldview embedded within a moral value system. Niyozov and Memon (2011) rightly argue that Islamic education during the Prophetic

6 'Așabiyyah: tribal solidarity. 
period was radical and transmitted a number of transformational goals. The Prophet established the foundations for acknowledging the "other" within their differences, but also recognised similarities and shared values. This transformation in human potential and values was not driven by rational reasoning at that stage, but rather by spiritual experience and moral drive (Bennabi 2006). The moral, spiritual element was the link that "cemented" various aspects of the new educational environment within which individuals were willingly directing their natural instincts, desires and energy towards their new ideals, goals and means. Bennabi (2006) analysis of the spiritual experience resonates in some of its aspects with Al-Ghazālī's conceptualisation of taste "dhawq", which is different from dhawq offered by mystics or from the rational reasoning of philosophers.

\subsubsection{Aesthetic Component to form Public Dhawq (Taste)}

A moral spiritual drive would display pitfalls if not nurtured with aesthetic taste and affinity that would refine the drive's application in context, so as to avoid the risk of turning into an arid and repulsive act (Bennabi 2006). Hence, a sensible action would require both the moral ethical drive and the aesthetic taste to adjust for the "right measure" of context. The moral component forms the framework for the aesthetic aspect (husn and jamāl) in social actions, reflected within ideas, behaviour, artefacts, dress codes, sounds, colours, smells, natural taste, material production, etcetera, to the level of "ihsān" (excellence). Regarded as a primary element, for Bennabi (2006), the aesthetic component shapes culture and determines identity and taste. In its broad sense, this aesthetic component influences personal identity, social relations, representations and customs. In a pluralistic context, it may also create areas of tension regarding what is considered tasteful and acceptable in the public sphere. For example, how to define art in education and refinement in behaviour? In addition, issues of hijab, niqab, statues, music, etcetera become part of public discussions on dhawq in Islamic schooling or Muslim visibility in the Western public arena. Although the influences within such tensions are complex, the aesthetic component forms an important part. Different empirical studies in Islamic/Muslim schools have raised critical questions about restrictions on music and/or art provision (McCreery et al. 2007; Halstead 1994). In this regard, McCreery et al. (2007) question:

Why do we educate children in certain ways and in certain subjects-why do we feel music and dance to be important aspects of children's education? We begin to recognise that it is our own cultural heritage that informs our choice of subjects, and we have to consider how valid this is for an education system that teaches children from other cultures. (McCreery et al. 2007, p. 212)

The discussion amongst Islamic schools' populations regarding the teaching of music and art demonstrates that Muslim educators, in their encounter with emerging challenges, continuously juggle and apply ethical judgments. In this sense, "practical wisdom" concerns the sensitive implementation of the possible choices as determined in particular social contexts. The school ethos required reflexive approaches to decide on the aesthetical expressions of moral values underpinning the cultural environment of these schools. Hence, efficacious action should be well-planned, organised and conscious rather reactionary or random action (Bennabi 2006).

\subsubsection{Freedom for Active Action ('amal)}

“Without freedom [we] cannot exist authentically."—Paulo Freire (Freire 1993, p. 48)

Ibn-Khaldūn (2005) regards assisting learners through the journey of fulfilling the purpose (ghāyah) and the scope (madá) of being human, as the central aim of education. Regarding the ghāyah of humanity, Ibn-Khaldūn defines it by succession (istikhläf) and leadership (ri'äsah). Determining the concept of madá, it appears through Ibn-Khaldūn's text as related to colonising the land (isti 'mār), in the materialist sense, to ensure the survival and empowerment of the human species. To achieve the ghāyah and achieve this madá of being a human, Ibn-Khaldūn (2005) stipulates the concepts of freedom 
and dignity—oppressive educational practice corrupts essential qualities. He noted that, when people are overpowered and subjugated, they lose the desire to achieve, be creative or defend themselves; rather, they become imitators of their oppressors.

This resonates, on different underlying assumptions, with Freire's concept of "alienation" where "the oppressed want at any cost to resemble the oppressors, to imitate them, to follow them" (Freire 1993, p. 44). Within the process of imitation, Bennabi (2006) argues people who lose their civilisation would miss identifying the systematic dynamic essence of the civilisation of the dominant. The consequence is a mere consumeristic approach to the dominant civilisation's objects and ideas detached from the spirit and origin of those ideas and objects, which aggravates the post-civilisational people's self-decline, lack of creativity and dependency. This resembles Freire (1993) notion of "dependency" that, the more estranged the oppressed become from self and one's heritage by internalising their oppressors' view of them, the more dependent they become. This, Freire (1993) argues, would result into a state of ambiguity, disempowerment and immobilisation to the sense of self-determination and social agency of those oppressed. The lack of freedom, Freire (1993) argues, can also lead to "fatalism" becoming a trait within oppressed societies as they "accept" their exploitation. However, for Fanon (1963), fatalism, embedded within violent oppression, manifests in contradictory ways, including aggression towards one's own community.

It is then worth questioning the nature of discipline in the school environment and what could be inheritably Islamic in terms of $t a$ ' $d \vec{\imath} b$ practices. "Rigorous discipline" is claimed to be one of "features, consistently associated with Islamic education", which makes it "inappropriate" to be regarded as a "high tradition", that is grafted upon and independent compared to "an earlier tradition of Orientalist scholarship" (Eickelman 1978, pp. 493-94). This swift generalisation of Islamic education is based on observations of the common practice of Qur'anic memorisation classes in a Moroccan context. Similar observations of harsh discipline were observed in some Qur'anic elementary classes in Britain (Halder 2015). However, Ibn-KhaldIbn-Khaldūn (2005) critically noted such contextual practices in his time and examined the differences in the taught curriculum, pedagogies, discipline, goals and the socio-political environment and their impact on learning. Ibn-Khaldūn (2005) rightly regarded strict discipline etiquettes between the teacher and the learner as a hindrance to the sense of freedom and dignity that would negatively affect the creativity of learners as they learn how to suppress their dignity and humiliate themselves to others. Furthermore, Ibn-Khaldūn (2005) considers violence and coercion in education to cause more corruption than good, by negatively affecting the physical, psychological and ethical behavioural aspects of learners. As for the psychological aspects, violence and coercion in educational practice negatively affect the happiness of the learner, their motivation and activity levels and their desire to work and be productive. As for its negative impact on the behavioural aspect, Ibn-Khaldūn (2005) presents two elements: passive and active. This would involve avoiding being oppressed and abused, as the learner develops habits of lying and malice and being two-faced. In addition, education based on intimidation and force results in the development of habits and morals, engaging deception towards others. Such consequences run contrary to nurturing wise moral action, as discussed above. To avoid such consequences, Ibn-Khaldūn (2005) proposes the Prophet's success in preserving the individuality and dignity of the Sahabas (Companions) as learners, while refining their wild Bedouin raw attitudes. Similarly, Bennabi considers such refinement as part of aesthetic development through moral spiritual and ethical drive, by directing spiritual energy towards creativity and action, while infusing "ihsān" (spiritual excellence), with its aesthetic aspect, into the action.

In this regard, prophet Yusuf in Egypt, based on the Qur'anic story (Quran: 12), could be regarded as one who had achieved spiritual freedom, knowledge and enjoyed the taste (dhawq) to the level of "ihs $\bar{a} n$ " in his conduct. These qualities provided Yusuf with the resilience to counter the challenging circumstances, thereby becoming creative and beneficial to the Egyptian society, which did not share his faith, and to his own kinship. Yusuf's model of hikmah combines ethics and moral values, freedom for choice and ihsan in action ('amal); an example that Muslim educators in Western contexts should seriously ponder upon in their endeavour to nurture creative and wise social actors. 


\section{Conclusions}

A key task for Islamic school leaders is to provide learners with an educational environment that exposes them to challenges and choices in society beyond the school gates and enables them to navigate life with confidence and positive action. It is not about reading Qur'anic verses and values in a superficial Islamic school environment, but rather to creatively act upon Qur'anic values in a challenging context. Accordingly, the "Islamic environment" emerges as a concept that needs further exploration with respect to "Islamic practice" because it is utilised by both Muslim educators and parents to discuss the Islamic ethos and school goals.

This leads to questions regarding how to create an educational environment based on Islamic values that stimulates learners' interests and desire to develop into creative social actors? This paper considers Bennabi's analysis of culture as a framework to argue for the need to consciously develop educational cultures that stimulate spirituality, aesthetics and thoughtful social action. Accordingly, this culture needs to nurture reflexive thought at the level of moral ethics and aesthetics; the two elements need to be embedded into the environment in its broader sense. However, for wise action to be achieved, the approach towards discipline regarding Islamic manners should penetrate deeper than a decorative "Islamicity" level of action; it should centre on transformation of the self by interconnecting goals, means and ends to secure social action. Promoting "freedom and dignity" constitutes an essential element beside Islamic morals, ethics and aesthetics. During such a process, rational reasoning is vital to be developed, but is insufficient to drive the deeply conscious ethical action from within, without the tazkiyah process of self-discipline.

Funding: The PhD research was funded by the University of Nottingham, UK. The follow-up research 2018-19 received no external funding.

Conflicts of Interest: The author declares no conflict of interest.

\section{References}

Abdalla, Mohamad, Dylan Chown, and Muhammad Abdullah. 2018. Islamic Schooling in the West: Pathways to Renewal. Cham: Palgrave Macmillan.

Abdel Haleem, Muhammad. 2005. The Qur'an: A New Translation, Oxford World's Classics. Oxford: Oxford University Press.

Al-Attas, Syed Muhammad Naquib. 1991. The Concept of Education in Islam: A Framework for an Islamic Philosophy of Education. Kuala Lumpur: International Institute of Islamic Thought and Civilization, International Islamic University.

Al-Faruqi, Ismail Raji. 1988. Islamization of Knowledge: Problems, principles and prospective. In Islam: Source and Purpose of Knowledge. Herndon: International Institute of Islamic Thought, pp. 15-63.

Al-Ghazali, Abu-Hamid. 1964. Mizan Al-'amal. Edited by Suleiman Dunya. Cairo: Dar Al-Ma'rif.

Al-Ghazali, Abu-Hamid. 2000a. Dear Beloved Son. Translated by Kamal El-Helbawy. Swansea: Awakening.

Al-Ghazali, Abu-Hamid. 2000b. The Incoherence of the Philosophers. Edited by Michael E. Marmura. Islamic Translation Series; Provo: Brigham Young University Press.

Al-Marzouqi, Abu Ya'rub. 2015. The Educational Reform of Ibn-Khaldūn and Ibn-Taymiyyah. Available online: https://abouyaarebmarzouki.wordpress.com/2015/06/01/\%d8\%aa7\%d9\%84\%d8\%a5\%d8\%b5\%d9\%84\%d8\% a7\%d8\%ad-\%d8\%a7\%d9\%84\%d8\%aa\%d8\%b1\%d8\%a8 $\%$ d9 $\% 88 \% d 9 \% 8 a-\% d 8 \% b 9 \% d 9 \% 86 \% d 8 \% a f-\% d 8 \%$ a7\%d8\%a $8 \%$ d9\%86-\%d8\%ae \%d9\%84\%d8\%af\%d9\%88\%d9\%86-\%d9\%88\%d8\%a7\%d8\%ar8 $\%$ d9 $\% 86-\% d 8 \%$ aa\%d9\%8a \%d9\%85/ (accessed on 13 June 2020).

Al-Zamakhshari, Mahmud. 2009. Al-Kashshāf' an haqā' iq at-tanzīl (The Discoverer of Revealed Truths), 3rd ed. Beirut: Al-M'a rifa.

The Association of Muslim Schools UK. 2019a. Frequently Asked Questions. AMS-UK. Available online: https://ams-uk.org/faq/ (accessed on 7 July 2020).

The Association of Muslim Schools UK. 2019b. Overview of Muslim Schools in the UK (2013). AMS-UK. Available online: https://ams-uk.org/muslim-schools-in-uk/ (accessed on 7 July 2020).

Ar-Rāzī, Fakhr ad-Dīn. 1981. Mafățīh Al-ghayb (The Keys to the Unknown). Beirut: Dar Al-Fikr, vol. 7. 
BBC. 2017. Jamia Al-Hudaa Residential College Faces New Criticism. Available online: https://www.bbc.co.uk/ news/uk-england-nottinghamshire-38891097 (accessed on 6 August 2020).

Bennabi, Malik. 2006. Shurūt Al-Nahda (Conditions of Renaissance), Problems of Civilization. Damscus: Dar-alFikr.

Cheruvallil-Contractor, Sariya, and Alison Scott-Baumann. 2015. Islamic Education in Britain: New Pluralist Paradigms. London: Bloomsbury.

Davids, Nuraan, and Yusef Waghid. 2019. Democratic Education and Muslim Philosophy: Interfacing Muslim and Communitarian Thought. Stellenbosch: Palgrave Pivot.

Department for Education (DfE). 2014. Guidance: Promoting Fundamental British Values through SMSC. Crown. Available online: https://assets.publishing.service.gov.uk/government/uploads/system/uploads/attachment_ data/file/380595/SMSC_Guidance_Maintained_Schools.pdf (accessed on 6 August 2020).

Eickelman, Dale F. 1978. The art of memory: Islamic education and its social reproduction. Comparative Studies in Society and History 20: 485-516. [CrossRef]

Fanon, Frantz. 1963. The Wretched of the Earth. London: Penguin Books.

Featherstone, Mike. 1990. Global culture: An introduction. In Global Culture: Nationalism, Globalization and Modernity. Edited by Mike Featherstone. London: Sage, pp. 1-14.

Freire, Paulo. 1993. Pedagogy of the Oppressed. New York: Continuum.

Gadamer, Hans-Georg. 1989. Truth and Method, 2nd rev. ed. Translated by Joel Weinsheimer, and Donald G. Marshall. London: Sheed \& Ward.

Gates, Brian. 2005. Faith schools and colleges of education since 1800. In Faith Schools: Consensus or Conflict? Edited by Roy Gardner, Denis Lawton and Jo Cairns. London: RoutledgeFalmer, pp. 15-36.

GOV.UK. 2019. Find and Compare Schools in England. Crown. Available online: https: //www.compare-school-performance.service.gov.uk/schools-by-type?step=phase\&geographic=all\& region $=0 \&$ phase $=$ secondary $\&$ for $=$ secondary \&basedon $=$ Overall $\% 20$ performance $\&$ show $=$ All $\% 20$ pupils (accessed on 6 August 2020).

GOV.UK. 2020. Schools, Pupils and Their Characteristics. Crown. Available online: https://explore-educationstatistics.service.gov.uk/data-tables (accessed on 5 July 2020).

GOV.UK. n.d. Types of School. Crown. Available online: https://www.gov.uk/types-of-school (accessed on 7 July 2020).

Halder, Alpona. 2015. Pedagogy and Discipline in Madrasas. Norderstedt: GRIN Publishing.

Halstead, J. Mark. 1994. Muslim attitudes to music in schools. British Journal of Music Education 11: 143-56. [CrossRef]

Halstead, J. Mark. 2004. An Islamic concept of education. Comparative Education 40: 517-29. [CrossRef]

Hashim, Rosnani, Suhailah Hussien, and Adesile Imran. 2014. Hikmah (wisdom) pedagogy and students' thinking and reasoning abilities. Intellectual Discourse 22: 119-38.

Haw, Kaye. 1994. Muslim girls' schools-A conflict of interests? Gender and Education 6: 63-76. [CrossRef]

Holmwood, John, and Therese O'Toole. 2018. Countering Extremism in British Schools? The Truth about the Birmingham Trojan Horse Affair. Bristol: Policy Press.

Ibn-'Āshūr, Muhammad Al-Ṭāhir. 1984. Al-Tahrīr wa Al-tanwīr (Liberation and Enlightenment). Tunis: Adar Al-Tunisia, vol. 3.

Ibn-Khaldūn, 'Abd Al-Rahmān. 2005. Al-Muqaddimah [The Introduction]. Edited by Abdesselam Cheddadi. Casablanca: Beit Al-funun wa Al-ulum wa Al-adab, vol. 3.

Ibn-Qayyim, Al-Jawziyya. 2008. Misbah Al-tafasir Al-Qura'niyya Al-jami' li-tafsir Ibn-Al-Qayyim Al-Jawziyya (The Lamp Qur'anic Commentaries: The Compiler of the Interpretation of Ibn Qayyim Al-Jawziyyah). Edit by Abdul-Rahman Al-Qammash. Beirut: Dar Al-kutub Al-'Ilmiyya. Available online: https://ia800302.us. archive.org/25/items/tafser_kaim/tkaim.pdf (accessed on 5 July 2020).

Ibn-Rushd, Abu Al-Walid Muhammad ibn Ahmad. 1997. Fasl Al-maqal fi taqrir ma bayna Al-shari'ah wa-Al-hikmah min Al-ittisal: Aw, wujub Al-nazar Al-'aqli wa-hudud Al-ta' wil [The Decisive Treatise: The Connection between Islamic Religious Law and Philosophy]. Edited by Muhammad 'Abid Jabiri. Silsilat Al-turath Al-falsafi Al-'Arabi, mu' allafat Ibn Rushd. Beirut: Markaz Dirasat Al-Wadah Al-'Arabiyah.

Iqbal, Muhammad. 1999. The Reconstruction of Religious Thought in Islam. Lahore: M. Ashraf.

Kroeber, Alfred Louis, and Clyde Kluckhohn. 1952. Culture: A Critical Review of Concepts and Definitions. Cambridge: Peabody Museum of Archaeology and Ethnology Harvard University. 
Lahmar, Fella. 2011a. Discourses in Islamic educational theory in the light of texts and contexts. Discourse: Studies in the Cultural Politics of Education 32: 479-95. [CrossRef]

Lahmar, Fella. 2011b. Exploring the Complexity: The Theoretical Journey of a Novice Researcher. Nottingham: The Nottingham Jubilee Press.

Lahmar, Fella. 2012. Dealing with Diversity in Muslim Schools in Britain. Ph.D. dissertation, University of Nottingham, Nottingham, UK.

Lahmar, Fella. 2019. The hybrid status of Muslim schools in Britain: Conditions of self-expression. In Education, Immigration and Migration. Edited by Arar Khalid, S. Brooks Jeffrey and Bogotch Ira. Bingley: Emerald Publishing Limited, pp. 285-301.

McCreery, Elaine, Liz Jones, and Rachel Holmes. 2007. Why do Muslim parents want Muslim schools? Early Years 27: 203-19. [CrossRef]

Memon, Nadeem, Dylan Chown, and Claire Alkouatli. 2020. Descriptions and enactments of Islamic pedagogy: Reflections of alumni from an Islamic Teacher Education Programme. Pedagogy, Culture E Society, 1-19. [CrossRef]

Nasr, Seyyed Hossein. 2016. Philosophical considerations of Islamic education-Past and future: Interview with Professor Seyyed Hossein Nasr. In Philosophies of Islamic Education: Historical Perspectives and Emerging Discourses. Edited by Nadeem Memon and Mujadad Zaman. London: Routledge.

Niyozov, Sarfaroz, and Nadeem Memon. 2011. Islamic education and Islamization: Evolution of themes, continuities and new directions. Journal of Muslim Minority Affairs 31: 5-30. [CrossRef]

Office for National Statistics. 2013. Full Story: What Does the Census Tell Us about Religion in 2011? Crown. Available online: http://www.ons.gov.uk/ons/dcp171776_310454.pdf (accessed on 5 July 2020).

The Office for Standards in Education Children's Services and Skills. 2019a. Official Statistics: Non-Association Independent Schools Inspections and Outcomes in England: August 2019. GOV.UK. Available online: https://www.gov.uk/government/statistics/non-association-independent-schools-inspections-andoutcomes-in-england-august-2019 (accessed on 7 July 2020).

The Office for Standards in Education Children's Services and Skills. 2019b. The education inspection framework. Crown. Available online: https://assets.publishing.service.gov.uk/government/uploads/system/uploads/ attachment_data/file/801429/Education_inspection_framework.pdf (accessed on 7 July 2020).

Parker-Jenkins, Marie, Dimitra Hartas, and Barrie A. Irving. 2005. In Good Faith: Schools, Religion and Public Funding. Aldershot: Ashgate.

Rahman, Fazlur. 1988. Islamization of knowledge: A response. American Journal of Islamic Social Sciences 5: 3-11.

Sahin, Abdullah. 2013. New Directions in Islamic Education: Pedagogy and Identity Formation. Markfield: Kube Publishing.

Star Academies. 2020. Star Schools. Available online: https://staracademies.org/about-us/star-academies/ (accessed on 7 July 2020).

(C) 2020 by the author. Licensee MDPI, Basel, Switzerland. This article is an open access article distributed under the terms and conditions of the Creative Commons Attribution (CC BY) license (http://creativecommons.org/licenses/by/4.0/). 